\title{
Evaluation of different modules for the management of tomato fruit borer, Helicoverpa armigera pest of tomato
}

\author{
B. L. Jakhar* and Suman \\ Centre of Excellence for Research on Pulses, S. D. Agricultural University, Sardarkrushinagar -385 506 (Gujarat), \\ INDIA \\ *Corresponding author. E-mail: bjakhar@rediffmail.com \\ Received: October 16, 2014; Revised received: March 2, 2015; Accepted: March 21, 2015
}

\begin{abstract}
Among, six modules tested against Helicoverpa armigera on tomato, the IPM module I consisting interspersing of 1 row of african marigold after every 8 rows of tomato as well as on the periphery of the plot and spray of neem based formulation gromin $1 \%$ EC @ $0.5 \mathrm{ml} / /$ on appearance of the first instar larvae.IPM module II was interspersing of 1 row of african marigold after every 8 rows of tomato as well as on the periphery of the plot spray of neem based formulation gromin $1 \%$ EC @ $0.5 \mathrm{ml} / /$ on appearance of the first instar larvae and two spray of HaNPV @ 350 LE/ ha alternated with neem oil @ $0.5 \%+0.1 \%$ soap solution.IPM module III consisting interspersing of 1 row of african marigold after every 8 rows of tomato as well as on the periphery of the plot and two spray of Beauvaria basiana @ $40 \mathrm{~g} / 10 \mathrm{I}$ at appearance of first instar larvae alternated with Nikuchhi @ $1.0 \%$. and IPM module IV are growing of african marigold after every 8 rows of tomato as well as on the periphery of the plot and two spray of HaNPV@ 350 LE/ha on appearance of first instar larvae followed by spray of Decidan 32.8\% EC @ 15ml/10 litre. The IPM module V was alternate spray of Polytrin c $44 \%$ EC @ 10ml/10 litre on appearance of first instar larvae and subsequent spray at 15 days intervals and Module VI was Control. IPM-IV module was found highly effective and economical for management of tomato fruit borer, Helicoverpa armigera and it exhibited least tomato fruit borer damage (3.44\%) and maximum tomato yield $(257.25 \mathrm{q} / \mathrm{ha})$. This research gave the best result to farmers for the control of $H$. armigera in tomato crops.
\end{abstract}

Keywords:, Bio-control, Helicoverpa, IPM, Tomato

\section{INTRODUCTION}

Tomato, Lycopersicon esculentum Mill, is an important vegetable crop grown all over the world. It is a rich source of several minerals and vitamins. Among various pests infesting this crop, tomato fruit borer is the major pest on the developing fruits and responsible for major yield loss in tomato. Helicoverpa armigera has been a major constraint in tomato and causing extensive damage to the fruits to the extent of about 50 60 per cent (Singh and Singh, 1977; Reddy et al., 2011; Reddy and Tangtrakulwanich, 2013). The larvae bore characteristic circular holes mostly near the calyx of green fruits. Indiscriminate use of the insecticides created a several problems in the ecosystem, deleterious effects on parasites and predators, residual hazards to man and domestic animals. It was desirable to replace them with some eco friendly insecticides or bio pesticide (Choudhary and Prabhuddha, 2010). Keeping in view, emphasis is being given particularly on the use of bio-control agents which can be suitably acceptable in pest management programme. Therefore, in the present investigation, efforts will be made to evolve IPM modules, using minimum synthetic toxic chemicals and utilizing pesticide alternates like bio- agents, including plant products and trap crops.

\section{MATERIALS AND METHODS}

Field experiments were conducted during 2009, 2010 and 2011 at Agricultural Research Station, SDAU, Ladol in randomized block design with tomato (var. Abhinav). To evaluate the effectiveness of integrated pest management modules in comparison with chemical modules against tomato fruit borer.

Abhinav tomato variety was transplant in field in August with the spacing of $90 \mathrm{~cm}$ row to row and 60 $\mathrm{cm}$ plant to plant distance maintained in a plot size of $20 \times 20 \mathrm{~m}$ for each module with four replication and tomato was grown in telephone method of planting. All the recommended agronomical practices were adopted to raise a good crop. Larval infestation levels were estimated by randomly examining 60 unripe fruit per plot (one fruit per plant) and recording the number of $H$. armigera larvae and damaged fruit (Kuhar et al., 2006). The plots were harvested when ready and the yield was recorded for each plot. Both undamaged (marketable) and damaged fruits from each replication and total number of fruits was counted at the time of harvest and number of damaged fruits due to $H$. armigera were recorded and converted to per cent. Yield 
Table 1. Larval population of $H$. armigera per plant in different treatments.

\begin{tabular}{lcccc}
\hline Treatments/ & \multicolumn{4}{c}{ Larval population/plant } \\
\cline { 2 - 5 } \multicolumn{1}{c}{ IPM Module } & $\mathbf{2 0 0 9 - 1 0}$ & $\mathbf{2 0 1 0 - 1 1}$ & $\mathbf{2 0 1 1 - 1 2}$ & Pooled \\
\hline M-I & $0.91(0.33)$ & $0.87(0.27)$ & $0.84(0.21)$ & $0.87(0.27)$ \\
M-II & $0.92(0.36)$ & $0.91(0.33)$ & $0.86(0.25)$ & $0.89(0.31)$ \\
M-III & $(0.96)(0.43)$ & $0.93(0.38)$ & $0.89(0.30)$ & $0.92(0.37)$ \\
M-IV & $0.84(0.21)$ & $0.80(0.15)$ & $0.78(0.11)$ & $0.80(0.15)$ \\
M-V & $0.82(0.18)$ & $0.83(0.20)$ & $0.80(0.15)$ & $0.81(0.17)$ \\
M-VI & $1.10(0.71)$ & $1.07(0.66)$ & $1.14(0.80)$ & $1.10(0.72)$ \\
\hline S.Em. \pm T & 0.023 & 0.0248 & 0.023 & 0.017 \\
YD X T & 0.069 & & & 0.018 \\
CV $\%$ & & 0.073 & 0.070 & 0.052 \\
Y X T & 5.055 & 5.49 & 5.34 & NS \\
\hline
\end{tabular}

*Figures outside parenthesis arc $\sin \sqrt{ } \mathrm{X}+0.5$ transformed values, while those in parenthesis are retransformed values

Table: 2 Per cent fruit damage in tomato, Lycopersicon esculentum after different treatments.

\begin{tabular}{lcccc}
\hline Treatments/ & \multicolumn{4}{c}{ Per cent fruit damage } \\
\cline { 2 - 4 } & $\mathbf{2 0 0 9 - 1 0}$ & $\mathbf{2 0 1 0 - 1 1}$ & $\mathbf{2 0 1 1 - 1 2}$ & Pooled \\
\hline M-I & $15.45(7.10)$ & $14.78(6.51)$ & $14.18(6.0)$ & $14.80(6.53)$ \\
M-II & $16.27(7.85)$ & $15.13(6.81)$ & $14.31(6.11)$ & $15.23(6.92)$ \\
M-III & $17.21(8.75)$ & $15.39(7.05)$ & $14.59(6.35)$ & $15.73(7.38)$ \\
M-IV & $11.56(4.01)$ & $10.52(3.33)$ & $9.98(3.0)$ & $10.68(3.44)$ \\
M-V & $11.39(3.90)$ & $10.79(3.51)$ & $10.15(3.11)$ & $10.77(3.50)$ \\
M-VI & $30.36(25.55)$ & $27.90(21.90)$ & $25.71(18.85)$ & $27.99(22.10)$ \\
S.Em. \pm T & 0.51 & 0.51 & 0.59 & 0.41 \\
CD a T $5 \%$ Y T T & 1.54 & 1.52 & 1.75 & 0.54 \\
CV \% & 6.09 & 6.53 & 7.98 & NS \\
\hline
\end{tabular}

*Figures outside parenthesis are percentage transformed angular values. Y x T $=\mathrm{CD}$ of year or treatments at $5 \%$ Level of significance

is the final parameter to compare the effectiveness of different treatments under study. The yield of six different treatments (Modules) was recorded separately from the net plot area and converted to hectare basis.

Treatments:

Module-I: Interspersing of 1 row of African marigold after every 8 rows of tomato as well as on the periphery of the plot Spray of neem based formulation gromin $1 \%$ EC@ $0.5 \mathrm{ml} / 1$ on appearance of the first instar larvae.

Module-II :Interspersing of 1 row of African marigold after every 8 rows of tomato as well as on the periphery of the plot Spray of neem based formulation gromin 1\% EC@0.5 ml /1 on appearance of the first instar larvae. Two spray of HaNPV@350 LE/ha alternated with neem oil @ $0.5 \%+0.1 \%$ soap solution

Module-III: Interspersing of 1 row of African marigold after every 8 rows of tomato as well as on the periphery of the plot Two spray of Beauvaria basiana @ 40g/10 1 at appearance of first instar larvae alternated with Nikuchhi@1.0\%.

Module-IV: Interspersing of 1 row of African marigold after every 8 rows of tomato as well as on the periphery of the plot Two spray of HaNPV@350 LE/ ha on appearance of first instar larvae. Spray of Decidan 32.8\% EC@15ml/10 litre.

Module-V: Alternate spray of Polytrin c 44 \% EC @ 10ml/10 litrel and Decidan 32.8\% EC@15ml/10 litre on appearance of first instar larvae and subsequent spray at 15 days intervals.

Module-VI - Control: blank or there is no use of any pesticide or bioagents.

\section{RESULTS AND DISCUSSION}

The data revealed that weekly larval counts of $H$. armigera were made to determine the impact of different 
Table: 3 Yield of tomato.

\begin{tabular}{|c|c|c|c|c|}
\hline \multirow{2}{*}{$\begin{array}{l}\text { Treatments/ } \\
\text { IPM Module }\end{array}$} & \multicolumn{4}{|c|}{ Yield q/ha } \\
\hline & $2009-10$ & 2010-11 & 2011-12 & Pooled \\
\hline M-I & 231.49 & 145.50 & 285.0 & 220.66 \\
\hline M-II & 222.96 & 150.50 & 294.50 & 222.65 \\
\hline M-III & 217.75 & 142.0 & 270.50 & 210.08 \\
\hline M-IV & 254.58 & 176.75 & 324.50 & 251.94 \\
\hline $\mathrm{M}-\mathrm{V}$ & 257.25 & 173.25 & 320.50 & 250.33 \\
\hline M-VI & 171.44 & 110.0 & 217.50 & 169.81 \\
\hline S.Em. $\pm \mathrm{T}$ & 5.89 & 3.89 & 7.36 & 3.17 \\
\hline Y X T & - & - & - & 5.89 \\
\hline $\mathrm{CD}$ at $5 \%$ & 17.52 & 11.57 & 21.89 & 9.49 \\
\hline $\begin{array}{ll}\text { CV } \% & \text { Y T }\end{array}$ & 5.22 & 5. & 5.16 & $\begin{array}{c}16.76 \\
5.87\end{array}$ \\
\hline
\end{tabular}

$\mathrm{Y} \times \mathrm{T}=\mathrm{CD}$ of year and treatments at $5 \%$ Level of significance

treatments on the larval population. Larval population of $H$. armigera differed significantly (5\% level of significance) in different IPM module in tomato (Table-1). Pooled results showed that minimum larval population per plant was found in IPM module-IV ( 0.15 larvae/ plant) which was at par with IPM module-V (0.17 larvae/ plant) followed by the IPM module-I (0.27 larvae/ plant) and maximum was found in control module (0.72 larvae/ plant).Similar results were also obtained by (Chundurwar et al., 1993) who also observed that application of endosulfan followed by NPV for reducing the larval population in chickpea.

Fruit damage: The results presented in Table- 2 revealed that all the modules were found significantly superior to control module in reducing the tomato fruit borer damage in tomato during all the years as well as in pooled results. Further, the IPM module-IV and IPM module-V were found at par and found equally effective to manage the tomato fruit borer damage as compared to the rest of the treatments. The pooled results show that IPM module-IV exhibited least tomato fruit borer damage (3.44\%) and in IPM module-V it was (3.58\%). Similar trends were observed during all the years. Our results agree with Kumar et al. (2011) who reported that the treatment with biorational insecticides $(B$. thuringiensis, B. bassiana, azadirachtin and nuclear polyhedrosis virus) significantly reduced pod damage by $H$. armigera and increased the yield

Tomato yield: Significantly maximum tomato fruit yield was obtained in the IPM module-V $(257.25 \mathrm{q} / \mathrm{ha})$ which was at par with the IPM module-IV (254.58q/ha) during 2009-10. During 2010-11 significantly the highest yield was obtained in IPM module-IV (176.75q/ha) which was at par with IPM module-V $(173.25 \mathrm{q} / \mathrm{ha})$. Similar trends were observed during 2011-12 and pooled results. The present finding is in conformity with finding of Singh et al. (1999) who reported that maximum yield was obtained in HaNPV treatments.

\section{Conclusion}

It was concluded that for the growing of tomato, $L$. esculentum, growing farmers of Gujarat are advised to adopt Integrated Pest Management practices interspersing of 1 row of african marigold after every 8 rows of tomato as well as on the periphery of the plot and two spray of HaNPV@350 LE/ha on appearance of first instar larvae followed by spray of Decidan 32.8\% EC @ $15 \mathrm{ml} / 10$ litre. A large gap exists between knowledge and adoption of IPM. Therefore, it is an urgent need of growers regarding Integrated Pest Management Thus, IPM not only helps in minimizing pest population ecologically but also is economical for the growers and safer to consumers.

\section{REFERENCES}

Choudhary Sarthak, and Ray Prabuddha (2010). Knowledge level and adoption of IPM techniques: A studyamong the vegetable growers of katwa subdivision, Bardhaman district. Indian Journal of_Agriculture Sciences, 44(3): $34-40$.

Chundurwar, R.D, Pawar, V.M. and Dhawandkar, S.D. (1993). Control of H._armigera Hub. With chemical and biological insecticides on chickpea Pestology, 17(9):31-33.

Kuhar, T.P., Nault, B.A., Hitchner, E.A., Speese III, J., (2006). Evaluation of action threshold based insecticide spray programs for tomato fruit worm management in fresh market tomatoes in Virginia. Crop Protection, 25:604-612.

Kumar, B., Singh, S., Verma, R.A., (2011). Management of Helicoverpa armigera in chick pea through synthetic and bio-rational insecticides. Annals of Plant Protection Science, 19:205-206.

Reddy, G.V.P., Kikuchi, R., Remolona, J.E., (2011). New mite species associated with certain plant species from Guam. Journal of Entomology Acarology Research. 2 (43): 41-46.

Reddy, G.V.P., Tangtrakulwanich, K., (2013). Action threshold treatment regimens for red spider mite and fruit borer on 
tomato. Fla. Entomology 96:1084-1096.

Singh, H. and Singh,G. (1977). Biological studies on Heliothis armigera Hubner in Punjab. Indian Journal of Entomology. 37(2):154-164.
Singh, Vikram, Mathur, N.M., Hussain, Akhter, Kalyan, R.K. and Sharma, G.K. (1999). Evaluation of some ecofriendly pesticides modules against H.armigera Hub. in tomato. Indian Journal of Applied Entomology, 13:71-74. 